\title{
BIOGEOGRAPHY OF THE FRESHWATER FISH OF THE IBERIAN PENINSULA
}

\author{
J. A. Hernando and M. C.-Soriguer \\ Faculty of Marine Science, University of Cádiz. Biology. Ap. de Correos no. 40. 11510 Puerto Real. Cádiz, Spain.
}

Keywords: Iberian fish, Distribution, Biogeography, Allochthonous species, Sectorisation, Iberian peninsula, .

\begin{abstract}
This paper reviews and presents new data on the composition and distribution of fish species in the continental waters of the Iberian Peninsula, and proposes a division of the Peninsula into three subregions: the Ebro-Cantabrian, the Atlantic and the Betico-Mediterranean, based on the distribution of the 45 species (native and endemic) in the 22 river basins with surface areas of 990 square kilometres or more.
\end{abstract}

\section{INTRODUCTION}

The Iberian Peninsula is enormously interesting from an ichthyological point of view. Located at the Southwestern tip of Europe, it is a point of contact between North Atlantic and tropical coastal fish fauna. Much of its coastline is on the Mediterranean, the Straits of Gibraltar, which separate the Mediterranean from the Atlantic, have always been more of a bridge than a barrier for North African and Iberian fauna.

The epicontinental fish fauna has also been affected by the geological history of the Peninsula. Possibilities for dispersion have been, and still are, limited, due to the isolation caused by the Pyrenees and the Straits of Gibraltar. The number of species relative to the surface area is lower than in the rest of Europe, leading to a comparatively less diverse ichthyofauna. Isolation, along with the orographic and climatic peculiarities of the Peninsula, has led to the development of endemisms. Most of the large rivers flow EastWest, to the Atlantic, and the variable rainfall means that many of the rivers are torrential, while others are confined to small survival areas in the long dry season (June - October). All of this means that extreme life conditions are imposed on the animals which live in the rivers, favouring the development of adaptation mechanisms.

From the point of view of the ecological characteristics of the rivers, the ecosystems forming a frontier between sea and freshwater should not be forgotten: estuaries, wetlands, coastal lagoons, marshlands and salt marshes, which for different periods, experience the alternating influences of sea and freshwater. The ecosystems of variable salinity lead us to consider marine species as forming part of the Iberian continental fauna.

\section{THE ICTHYOFAUNA OF THE IBERIAN PENINSULA}

MYERS (1960) classified freshwater fish into three categories: primary, secondary and peripheral (vicariant, diadromous, sporadic and complementary). Under this classification, the continental fauna of the Iberian Peninsula consists of 64 species in 24 families (table 1). Of these, 45 are autochthonous (native or endemic) and 19 allochthonous, with differing degrees of acclimatization (SOSTOA et al., 1984; ICONA, 1986). To these we should add 18 sporadic or sedentary marine species which thrive in the estuaries, marshlands, coastal lagoons, marshes and salt flat ecosystems, and belong to 16 marine families (table 2), raising the number of species to 98 .

The taxonomy of the species has been studied by ALMAÇA (1964, 1967, 1972), COLLARES-PEREIRA (1983), DOADRIO (1984, 1987) and ELVIRA (1987), and their distribution in some river basins by HERNANDO (1975a, 1975b), DEMESTRE et al., (1977), GARCIA DE JALON \& GONZALEZ DE TANAGO (1983), GARCIA DE JALON \& LOPEZ (1983), FERNANDEZ-DELGADO et al., (1986), LOBON-CERVIA et al., (1989) and SOSTOA \& LOBON-CERVIA (1989). 
Table 1. Freshwater fish fauna of the Iberian peninsula. Type is the character of the specie (N: native; E: endemic: I: introduced, with date of introduction in brackets). Con. is the present preservation according to ICONA (1986) and LOBON-CERVIA \& ELVIRA (1989); here we have used the IUCN categories. (I: indeterminate; IC: insufficient knowledge; NA: not endangered; P: endangered; R: rare; V: vulnerable). A: anadromous; C: catadromous; F and B: fresh and salt water.

\begin{tabular}{|c|c|c|c|c|c|}
\hline \multicolumn{3}{|l|}{ Scientific name } & \multirow[t]{2}{*}{ Common name } & \multirow[t]{2}{*}{ Type } & \multirow[t]{2}{*}{ Con. } \\
\hline Familia Petromyzontidae & $3.12 \%$ & & & & \\
\hline Lampetra planeri & $(\mathrm{LN})$ & $\mathrm{F}$ & Lamprea de río & $\mathbf{N}$ & $\mathrm{R}$ \\
\hline Petromyzon marinus & $(\mathrm{PM})$ & A & Lamprea marina & $\mathrm{N}$ & I \\
\hline Familia Acipenseridae & $1.56 \%$ & & & & \\
\hline Acipenser sturio & (AS) & A & Esturión o sollo & $\mathrm{N}$ & $\mathrm{P}$ \\
\hline Familia Clupeidae & $3.12 \%$ & & & & \\
\hline Alosa alosa & (AA) & A & Sábalo & $\mathrm{N}$ & $\mathrm{V}$ \\
\hline Alosa fallax & (AF) & A & Saboga & $\mathrm{N}$ & $\mathrm{V}$ \\
\hline Familia Angullidae & $1.56 \%$ & & & & \\
\hline Anguilla anguilla & $(\mathrm{AG})$ & $\mathrm{C}$ & Anguila & $\mathrm{N}$ & $\mathrm{V}$ \\
\hline Familia Salmoidae & $7.81 \%$ & & & & \\
\hline Hucho hucho & (HH) & $\mathrm{F}$ & Huchón & I (1968) & $\mathrm{R}$ \\
\hline Salmo fontinalis & (SF) & $\mathrm{F}$ & Salvelino & I (XIX) & $\mathrm{R}$ \\
\hline Salmo gaidneri & (SG) & $\mathrm{F}$ & Trucha arco iris & I (XIX) & NA \\
\hline Salmo salar & (SS) & A & Salmón & $\mathrm{N}$ & $\mathrm{V}$ \\
\hline Salmo trutta trutta & (STT) & $\mathrm{F}$ & Trucha común & $\mathrm{N}$ & NA \\
\hline Salmo trutta fario & (STF) & B & Trucha marisca o reo & $\mathrm{N}$ & NA \\
\hline Familia Esocidae & $1.56 \%$ & & & & \\
\hline Esos lucius & (ES) & $\mathrm{F}$ & Lucio & 1 (1949) & NA \\
\hline Familia Cyprinidae & $35.94 \%$ & & & & \\
\hline Anaecypris hispanica & $(\mathrm{AH})$ & $\mathrm{F}$ & Jarabugo & E & $\mathrm{R}$ \\
\hline Barbus bocagei bocagei & (BBB) & $\mathrm{F}$ & Barbo ibérico & $\mathrm{E}$ & NA \\
\hline Barbus bocagei graellsi & (BBG) & $\mathrm{F}$ & B. ibérico de Graells & E & NA \\
\hline Barbus bocagei sclateri & (BBS) & $\mathrm{F}$ & B. ibérico de Sclater & E & NA \\
\hline Barbus comiza & (BC) & $\mathrm{F}$ & Barbo comiza o comiza & E & NA \\
\hline Barbus haasi & $(\mathrm{BH})$ & $\mathrm{F}$ & Barbo culirroyo & E & NA \\
\hline Barbus meridionalis & (BM) & $\mathrm{F}$ & Barbo de montaña & $\mathrm{N}$ & NA \\
\hline Barbus microcephalus & (BP) & $\mathrm{F}$ & Barbo cabecicorto & $\mathrm{E}$ & IC \\
\hline Carassius auratus & (CP) & $\mathrm{F}$ & Carpín dorado & I? & IC \\
\hline Carassius carassius & (CA) & $\mathrm{F}$ & Carpín & I (XVII) & NA \\
\hline Cyprinus carpio & (CC) & $\mathrm{F}$ & Carpa & I (II b C) & NA \\
\hline Chondrostoma polylepis polylepis & (CPP) & $\mathrm{F}$ & Boga de río & $\mathrm{E}$ & NA \\
\hline Chondrostoma polylepis willkommi & $(\mathrm{CPW})$ & $\mathrm{F}$ & Boga del Guadiana & E & NA \\
\hline Chondrostoma toxostoma toxosostma & (CTT) & $\mathrm{F}$ & Madrilla & $\mathrm{N}$ & NA \\
\hline
\end{tabular}


Table 1. Freshwater fish fauna of the Iberian peninsula. Type is the character of the specie (N: native; E: endemic; I: introduced, with date of introduction in brackets). Con. is the present preservation according to ICONA (1986) and LOBON-CERVIA \& ELVIRA (1989); here we have used the IUCN categories. (I: indeterminate; IC: insufficient knowledge; NA: not endangered; P: endangered; R: rare; V: vulnerable). A: anadromous; C: catadromous; F and B: fresh and salt water.

\begin{tabular}{|c|c|c|c|c|c|}
\hline Scientific name & & & Common name & Type & Con. \\
\hline Chondrostoma toxostoma arrigonis & (CTA) & $\mathrm{F}$ & Madrilla & $\mathrm{N}$ & NA \\
\hline Gobio gobio & $(G G)$ & $\mathrm{F}$ & Gobio & $\mathrm{I}(\mathrm{XIX})$ & NA \\
\hline Iberocypris palaciosi & (IP) & $\mathrm{F}$ & Bogardilla & $\mathrm{E}$ & IC \\
\hline Leuciscus carolitertis & $(\mathrm{LT})$ & $\mathrm{F}$ & Cacho & $\mathrm{E}$ & IC \\
\hline Leuciscus cephalus & (LC) & $\mathrm{F}$ & Bagre & $\mathrm{N}$ & NA \\
\hline Leuciscus pyrenaicus & $(\mathrm{LP})$ & $\mathrm{F}$ & Cachuelo & $\mathrm{E}$ & IC \\
\hline Phoxinus phoxinus & $(\mathbf{P P})$ & $\mathrm{F}$ & Piscardo & $\mathrm{E}$ & NA \\
\hline Rutilus alburnoides & (RB) & $\mathrm{F}$ & Calandino & $\mathrm{E}$ & NA \\
\hline Rutilus arcasii arcasii & (RAA) & $\mathrm{F}$ & Bermejuela & $\mathrm{E}$ & NA \\
\hline Rutilus arcasii macrolepidotus & (RAM) & $\mathrm{F}$ & Bermejuela & $\mathrm{E}$ & NA \\
\hline Rutilus lemmingii & (RL) & $\mathrm{F}$ & Pardilla & $\mathrm{E}$ & NA \\
\hline Rutilus rutilus & (RR) & $\mathrm{F}$ & & $I(1910 \mathrm{~s})$ & NA \\
\hline Scardinius erythrophthalmus & (SE) & $\mathrm{F}$ & Gardí & $\mathrm{I}(1910 \mathrm{~s})$ & $\mathrm{R}$ \\
\hline Tinca tinca & $(\mathrm{TT})$ & $\mathrm{F}$ & Tenca & $\mathrm{N}$ & NA \\
\hline Familia Cobitidae & $3.12 \%$ & & & & \\
\hline Cohitis calderoni & (CD) & $\mathrm{F}$ & Lamprehuela & $\mathrm{E}$ & IC \\
\hline Cohitis maroccana & $(\mathrm{CM})$ & $\mathrm{F}$ & Colmilleja & $\mathrm{E}^{*}$ & $\mathrm{~V}$ \\
\hline Familia Homalopteridae & $1.56 \%$ & & & & \\
\hline Noemacheilus barbatulus & $(\mathrm{NB})$ & $\mathrm{F}$ & Lobo de río & $\mathrm{N}$ & NA \\
\hline Familia Siluridae & $1.56 \%$ & & & & \\
\hline Silurus glanis & $(\mathrm{SN})$ & $\mathrm{F}$ & Siluro & I (1970s) & NA \\
\hline Familia Ictaluridae & $1.56 \%$ & & & & \\
\hline Ictalurus melas & (IM) & $\mathrm{F}$ & Pez gato & $\mathrm{I}(1910 \mathrm{~s})$ & IC \\
\hline Familia Cyprinodontidae & $4.69 \%$ & & & & \\
\hline Aphanius iherus & $(\mathrm{AI})$ & FB & Fartet & $E^{*}$ & $P$ \\
\hline Fundulus heteroclitus & $(\mathrm{FH})$ & FB & & I (1960s) & NA \\
\hline Valencia hispanica & $(\mathrm{VH})$ & FB & Samaruc & $\mathrm{E}$ & $\mathbf{P}$ \\
\hline Familia Poecillidae & $1.56 \%$ & & & & \\
\hline Gambusia affinis & (GF) & FB & Gambusia & I (1921) & NA \\
\hline Familia Atherinidae & $1.56 \%$ & & & & \\
\hline Atherina hoyeri & $(\mathrm{AY})$ & FB & Pejerrey & $\mathrm{N}$ & NA \\
\hline
\end{tabular}

* Endemism Iberian North-African 
Table 1. Freshwater fish fauna of the Iberian peninsula. Type is the character of the specie (N: native; E: endernic; I: introduced, with date of introduction in brackets). Con. is the present preservation according to ICONA (1986) and LOBON-CERVIA \& ELVIRA (1989); here we have used the IUCN categories. (I: indeterminate; IC: insufficient knowledge; NA: not endangered; P: endangered; R: rare; V: vulnerable). A: anadromous; C: catadromous; F and B: fresh and salt water.

\begin{tabular}{|c|c|c|c|c|c|}
\hline \multicolumn{3}{|l|}{ Scientific narne } & \multirow[t]{2}{*}{ Common name } & \multirow[t]{2}{*}{ Type } & \multirow[t]{2}{*}{ Con. } \\
\hline Familia Gasterosteidae & $1.56 \%$ & & & & \\
\hline Gasterosteus aculeatus & $(\mathrm{GA})$ & FB & Espinoso & $\mathrm{N}$ & $\mathrm{V}$ \\
\hline Familia Syngnathidae & $1.56 \%$ & & & & \\
\hline Syngnathus abaster & $(\mathrm{SA})$ & FB & Aguja de río & $\mathrm{N}$ & $\mathrm{V}$ \\
\hline Familia Cottidae & $1.56 \%$ & & & & \\
\hline Cottus gobio & (CG) & $\mathrm{F}$ & Cavilat & $\mathrm{N}$ & $\mathrm{P}$ \\
\hline Familia Percidae & $3.12 \%$ & & & & \\
\hline Perca fluviatilis & $(\mathrm{PF})$ & $\mathrm{F}$ & Perca & $\mathrm{I}(1970 \mathrm{~s})$ & $\mathrm{IC}$ \\
\hline Stizostedion lucioperca & (SL) & $\mathrm{F}$ & Lucioperca & I $(1970 s)$ & IC \\
\hline Familia Moronidae & $3.12 \%$ & & & & \\
\hline Dicentrarchus labrax & (DL) & FB & Lubina o Robálo & $\mathrm{N}$ & NA \\
\hline Dicentrarchus punctata & (DT) & FB & Baila & $\mathrm{N}$ & NA \\
\hline Familia Centrarchidae & $3.12 \%$ & & & & \\
\hline Lepomis gibbosus & (LG) & $\mathrm{F}$ & Perca sol & I (1910s) & NA \\
\hline Micropterus salmoides & $(\mathrm{MS})$ & $\mathrm{F}$ & Perca americana & I (1955) & NA \\
\hline Familia Mugilidae & $7.81 \%$ & & & & \\
\hline Chelon labrosus & $(\mathrm{CL})$ & FB & Lisa & $N$ & NA \\
\hline Liza aurata & (LA) & FB & Galupe & $N$ & NA \\
\hline Liza ramada & (LR) & FB & Morragute o albur & $\mathrm{N}$ & NA \\
\hline Lizu saliens & $(\mathbf{L S})$ & FB & Galúa o Cachorreña & $\mathrm{N}$ & NA \\
\hline Mugil cephalus & $(\mathrm{MC})$ & FB & Capitán o pardete & $\mathrm{N}$ & NA \\
\hline Familia Blennidae & $1.56 \%$ & & & & \\
\hline Blennius fluviatilis & $(\mathrm{BF})$ & $\mathrm{F}$ & Fraile & $\mathrm{N}$ & $\mathrm{E}$ \\
\hline Familia Gobiidae & $3.12 \%$ & & & & \\
\hline Pomatoschistus microps & $(\mathrm{PC})$ & $\mathrm{FB}$ & Cabuxino enano & $\mathrm{N}$ & NA \\
\hline Pomatoschistus minutus & $(\mathrm{PT})$ & FB & Cabuxino & $\mathrm{N}$ & NA \\
\hline Familia Pleuronectidae & $1.56 \%$ & & & & \\
\hline Platichthys flexus & $(\mathrm{PF})$ & FB & Platija & $\mathrm{N}$ & NA \\
\hline Familia Cichlidae & $1.56 \%$ & & & & \\
\hline Cichlasonza facetum & (CF) & $\mathrm{F}$ & Chanchito & I (1930s) & IC \\
\hline
\end{tabular}


The Cyprinidae genera which inhabit the southern provinces originated in Siberia, and arrived in Europe through the drying out of the Sea of Obi during the Holocene period, the time of Alpine orogenesis, when the Pyrenees were formed. During the same period, the Oligocenic transgression divided Europe allowing communication of the North Sea and the Tethys Sea via Southern Russia (TERMIER, 1960).

Both of these created a great barrier to the arrival of freshwater fish in the Iberian Peninsula (MYERS, 1960; BANARESCU, 1972), and therefore the colonization of the Peninsula must have happened before the end of the Oligocene.

The Siberian immigrants (BANARESCU, 1973a, 1973b) are of the genera Pseudophoxinus (Phoxinellus), Tropidophoxinellus, Tinca, Chondrostoma, Rutilius and Leucisus; and the Barhus from East Asia. The differentiation of species such as Barhus meridionalis appears to arise in to this period, while the Iberian endemisms of post-Oligocenic formation, possibly during the Pontiense, form two groups. The first, with geographical and ecological incompatibilities with the North African Cyprinidae, comprises the species Barhus bocagei graellsi, Barhus hocagei hocagei, Chrondrostoma polyepis polypepis and Chrosdrostoma tosostoma arrigonis and the second group, possibly formed well into the Pontiense, and which is geographically and ecologically compatible with the North African Cyprinidae, includes Barhus barbus sclarteri. Barbus comiza, Barhus microcephalus, Chondrostoma polyepis willkommi, Leuciscus pyrenaicus, Rutilus arcasi, Rutilus lemmingii and Rutilus alburnoides.

According to ALMAÇA (1976) and ELVIRA (1986), the Rutilus genus, still of uncertain taxonomy due to the intermediate features of the population at both species and genus levels, may represent a speciation or sub-speciation.

Cobitidae and Homalopteridae are of Euro-Mediterranean origin. In the case of Cobitidae a speciation may have occurred in the Peninsula, in such a way that one species is related to the Euro-Mediterranean and the other endemism to the North African fauna (Cohitis maroccana), underlining the fact that both are considered endemisms, the former Iberian and the latter Iberian-North African.

\section{THE CYPRINIDAE GENERA}

The Barbus genera has been considered to include Barbus barbus, Barhus comiza and Barhus meridionalis, considering the first and last having two subspecies: B. h. hocagei,
B. h. sclateri, B. m. meridionalis and B. m. graellsi (LOZANO, 1935). Later, ALMAÇA (1967), revising the genera, considered that it was necessary to raise some subspecies such as B. sclateri, B. bocagei, B. graellsi. B. comiza was maintained, and two new species were defined: $R$. microcephalus and B. steindachneri. Finally, DOADRIO (1984) changed the taxonomy, classifying five species, B. bocagei, B. comiza, B. haasi, B. microcephalus and B.meridionalis, all without subspecies except for the first, the Iberian barbel, which he divided into 3 subspecies: $B . h$. hocagei, B. h. graellsi and B. h. sclateri.

As for zoogeographical origin, ALMAÇA (1984) divides Iberian barbels into two groups: I (bocagei, graellsi and sclateri), together with North African and Asian barbels, and II (comiza, microcephalus and steindachneri) related to Western Asian and North African barbels.

There are two species of the Chondrostoma genus in the Iberian Peninsula, Ch. polylepis and Ch. toxostoma. The first is endemic, and is distributed throughout the Atlantic river basins, while the second is native, with a CantabrianMediterranean distribution.

Each is divided into two subspecies: parental (Ch. p. polylepis and Ch. t. toxostoma) and Ch. p. willkommi and $C h$. $t$. arrigonis. They have very different distributions: the parental subspecies (Ch.p. polylepis and Ch.t. toxostoma) are to be found in the north, and Ch. p. willikommi and Ch. t. arrigonis in the south (ELVIRA, 1987).

The Rutilus genus has so far had a more uncertain classification (COLLARES-PEREIRA, 1984; ELVIRA, 1987) since some of the species included have shifted between Leuciscus, Chondrostoma, Pararutilus, Rutilus and Tropidophoxinellus genera. At present it is considered to be formed by two species, $R$. arcasii and $R$. lemmigii.

The first has two subspecies, the parental. distributed throughout the northern river basins, and R. a. macrolepidotus, found in North West Portugal, between the Limia and the Tajo, and in the Duero basin. Both are endemic to the Peninsula. (LOBON-CERVIA et al., 1989) include the subspecies $R$. a. macrolepidotus as a species in the text and in Table I of a paper, but do not include it in Table 2, referring to its relict distribution in the most westerly streanis.

Here we must refer to another endemism, Tropidophoxinellus alburnoides, which was included in the same genera as R. alburnoides. Due to its peculiar biological characteristics, the presence of two different genotypical groups $(2 n=50 ; 3 n$ $=75$ ) and triploid associated gynogenesis and the production of clonic females, the "Rutilus alburnoides Complex" (COLLARES-PEREIRA, 1984, 1985) was created. 
Table 2. Marine dependent species found in the estuaries, wetlands, marshes, salt flats, and brackish or salty lagoons of the Iberian Peninsula.

\begin{tabular}{|c|c|}
\hline Familia Ammodytidae & Familia Pomatomidae \\
\hline Ammodytes tobianus & Pomatomus saltator \\
\hline \multicolumn{2}{|l|}{ Gymmnamodytes cicerellus } \\
\hline & Familia Sciaenidae \\
\hline Familia Batrachoididae & Argirosomus regius \\
\hline Halobatrachus didactylus & $\begin{array}{l}\text { Umbrina canariensis } \\
\text { Umbrina cirrosa }\end{array}$ \\
\hline \multicolumn{2}{|l|}{ Familia Blennidae } \\
\hline Blennius pavo & $\begin{array}{l}\text { Familia Soleidae } \\
\text { Dicologoglosa cuneta }\end{array}$ \\
\hline Familia Bramidae & Solea senegalensis \\
\hline Brama brama & Solea vulgaris \\
\hline Familia Clupeidae & Familia Sparidae \\
\hline Sardina pilchardus & $\begin{array}{l}\text { Diplodus sargus } \\
\text { Litognathus mormyrus }\end{array}$ \\
\hline \multicolumn{2}{|l|}{ Engraulis eucrasicholus } \\
\hline & Familia Stromateidae \\
\hline $\begin{array}{l}\text { Familia Gobiidae } \\
\text { Aphia minuta }\end{array}$ & Stromateus fiatola \\
\hline Gobius niger & Familia Syngnathidae \\
\hline Gohius paganellus & Hippocampus hippocampus \\
\hline \multicolumn{2}{|l|}{ Gobius cruentatus } \\
\hline & Familia Trachinidae \\
\hline Familia Mugilidae & Echiichthys vipera \\
\hline Oeadalechilus labeo & \\
\hline \multicolumn{2}{|l|}{ Familia Mullidae } \\
\hline Mullus barbatus & \\
\hline Mullus surmuletus & \\
\hline
\end{tabular}

It was finally decided (ELVIRA, 1987) to include it in the Tropidophoxinellus genus, fully acknowledging the need for athorough review. Furthermore, LOBON-CERVIA et al., (1989) consider it as belonging to the Rutilus genus, and LOBON-CERVIA \& ELVIRA (1989) as Tropidophoxinellus.

In addition, the Iberian endemism Anaecypris hispanica has a complex taxonomy, and has been included in the Phoxinellus and Pseudophoxinellus genera. Its distribution, limited to the Guadiana basin, has been enlarged since its capture in the River Bembezar (Azuaga, Bajadoz), an affluent of the River Guadalquivir (DOADRIO, 1986).
As for the Leuciscus genus, similar problems have arisen, although traditionally (LOZANO, 1935; BUEN, 1935) it has been considered as comprising the species Leuciscus cephalus with two subspecies: L. c. cabeda in the north and L.c. pyranaicus in the south. However, DOADRIO (1987) has revised the genus, concluding that there are three species: $L$. cephalus, L. carolitertis and L. pyrenaicus. For the time being, and until the distribution of $L$. carolitertis is better known, it is restricted to the Duero basin. This suggests that this is a case of speciation similar to that of Rutilus, possibly due to the effect of glaciations.

Our own opinion, however, is in line with that of ALMAÇA (1976) and ELVIRA (1986), in that it is necessary to review thoroughly the Rutilus and Leuciscus genera, and determine the distribution of each species.

The group of strictly freshwater species is formed by the Cyprinidae, Cobitidae and Homalopterdae, and two vicariant species: Blennius fluviatilis and Cottus gobio, both with a very concise distribution (table 3 ). Cyprinidae, Cobitidae and Homalopteridae have the largest number of endemic or native species. Of a total of 26 species (40.62\% of fish fauna), 15 are endemic $(23.42 \%), 5$ are native (7.8\%) and $6(9.4 \%)$ introduced.

\section{ALLOCHTHONOUS SPECIES}

The introduction of allochthonous species in the Iberian peninsula began with the Romans, who acclimatised the carp, Cyprinus carpio, which today, with 19 species, makes up $29.7 \%$ of the total Iberian continental fish fauna. Their distribution among the river basins is unequal, with the lowest number of introduced species being found in the South of Spain (4) and the highest in the rivers of the Eastern Pyrenees, where 12 species in all have been found. These two areas include the five large river basins: the Ebro, Guadalquivir, Guadiana and Tajo, with 10 introduced species, and the Duero, with 8 (table 3 ).

The origins of these species, and the reasons for their introduction, are several. Firstly, there are "accidental" introductions, mainly escapes from fish farms, where these fish were raised for sale or as live food for other species (brown trout, rainbow trout, grudgeon). These accidental introductions also include Scardinius erythophtalmus, Ictalurus melas and Silurus glanis. The government has caused other introductions: Esox lucius, Microterus salmoides, Lepomis gibbosus etc., for angling, and Gambussia affinis for health reasons (malaria control). Esox lucius, on the other hand, is 
Table 3. Distribution of the species in the different river basins. The codes used are those of Table 4 and figure 1.

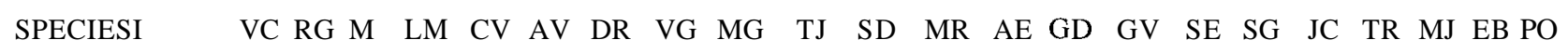
BASINS

\begin{tabular}{|c|c|c|c|c|c|c|c|c|c|c|c|c|c|c|c|c|c|c|c|c|c|c|}
\hline L. planeri & 1 & 1 & 1 & 1 & 1 & 1 & 0 & 0 & 0 & 0 & 0 & 0 & 0 & 0 & 0 & 0 & 0 & 0 & 0 & 0 & 0 & 0 \\
\hline P. marinus & 1 & 1 & 1 & 0 & 0 & 0 & 0 & 1 & 0 & 0 & 0 & 0 & 0 & 0 & 1 & 0 & 0 & 0 & 0 & 0 & 1 & 0 \\
\hline A. sturio & 0 & 0 & 0 & 0 & 0 & 0 & 1 & 0 & 0 & 1 & 0 & 0 & 0 & 1 & 1 & 0 & 0 & 0 & 0 & 0 & 0 & 0 \\
\hline A. alosa & 1 & 1 & 1 & 1 & 1 & 1 & 1 & 1 & 1 & 1 & 1 & 0 & 0 & 1 & 1 & 0 & 1 & 0 & 0 & 0 & 1 & 0 \\
\hline A. fallax & 1 & 1 & 1 & 0 & 0 & 0 & 1 & 1 & 0 & 1 & 1 & 0 & 0 & 1 & 1 & 0 & 0 & 1 & 0 & 0 & 1 & 0 \\
\hline A. anguilla & 1 & 1 & 1 & 1 & 1 & 1 & 1 & 1 & 1 & 1 & 1 & 1 & 1 & 1 & 1 & 1 & 1 & 1 & 1 & 1 & 1 & 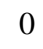 \\
\hline H. hucho & 0 & 0 & 0 & 0 & 0 & 0 & 1 & 0 & 0 & 0 & 0 & 0 & 0 & 0 & 0 & 0 & 0 & 0 & 0 & 0 & 0 & U \\
\hline S. fontinalis & $\mathrm{O}$ & 0 & 0 & 0 & 0 & 0 & 1 & 0 & 0 & 1 & 0 & 0 & 0 & 0 & 0 & 0 & 0 & 0 & 0 & 0 & 1 & 0 \\
\hline S. gaidneri & 1 & 1 & 1 & 1 & 1 & 1 & 1 & 0 & 0 & 1 & 0 & 0 & 0 & 1 & 1 & 0 & 1 & 1 & 1 & 0 & 0 & 1 \\
\hline S. salar & 1 & 1 & 1 & 0 & 0 & 0 & 0 & 0 & 0 & 0 & 0 & 0 & 0 & 0 & 0 & 0 & 0 & 0 & 0 & 0 & 0 & 0 \\
\hline S. t. trutta & 1 & 1 & 1 & 1 & 1 & 1 & 1 & 1 & 1 & 1 & 0 & 0 & 0 & 1 & 1 & 1 & 1 & 1 & 1 & 1 & 1 & 1 \\
\hline S. $t$. fario & 1 & 1 & 1 & 1 & 1 & 1 & 1 & 0 & 0 & 0 & 0 & 0 & 0 & 0 & 0 & 0 & 0 & 0 & 0 & 0 & 0 & 0 \\
\hline E. lucius & 1 & 1 & 1 & 1 & 1 & 1 & 1 & 1 & 1 & 1 & 1 & 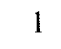 & 1 & 1 & 1 & 0 & 1 & 1 & 1 & 1 & 1 & 1 \\
\hline A. hispanica & 0 & 0 & 0 & 0 & 0 & 0 & 0 & 0 & 0 & 0 & 0 & 0 & 0 & 1 & 1 & 0 & 0 & 0 & 0 & 0 & 0 & 0 \\
\hline B.b. bocagei & 0 & 0 & 0 & 1 & 1 & 1 & 1 & 1 & 1 & 1 & 1 & 1 & 0 & 0 & 0 & 0 & 0 & 1 & 1 & 0 & 0 & 0 \\
\hline B. b. graellsi & 1 & 0 & 0 & 0 & 0 & 0 & 0 & 0 & 0 & 0 & 0 & 0 & 0 & 0 & 0 & 0 & 0 & 0 & 0 & 0 & 1 & 1 \\
\hline B.h. sclateri & 0 & 0 & 0 & 0 & 0 & 0 & 0 & 0 & 0 & 0 & 0 & 0 & 1 & 1 & 1 & 1 & 1 & 0 & 0 & 0 & 0 & 0 \\
\hline B. comiza & 0 & 0 & 0 & 0 & 0 & 0 & 0 & 0 & 0 & 1 & 1 & 1 & 1 & 1 & 0 & 0 & 0 & 0 & 0 & 0 & 0 & 0 \\
\hline B. haasi & 0 & 0 & 0 & 0 & 0 & 0 & 0 & 0 & 0 & 0 & 0 & 0 & 0 & 0 & 0 & 0 & 0 & 1 ? & 1 ? & 0 & 1 & 1 \\
\hline B. meridionalis & 0 & 0 & 0 & 0 & 0 & 0 & 0 & 0 & 0 & 0 & 0 & 0 & 0 & 0 & 0 & 0 & 0 & 0 & 0 & 0 & 0 & 1 \\
\hline B. microcephalus & 0 & 0 & 0 & 0 & 0 & 0 & 0 & 0 & 0 & 1 & 0 & 0 & 0 & 1 & 0 & 0 & 0 & 0 & 0 & 0 & 0 & 0 \\
\hline C. auratus & 1 & 1 & 1 & 1 & 1 & 1 & 1 & 1 & 1 & 1 & 1 & 1 & 1 & 1 & 1 & 0 & 1 & 1 & 1 & 1 & 1 & 1 \\
\hline C. carassius & 0 & 0 & 0 & 0 & 0 & 0 & 0 & 0 & 0 & 0 & . & 0 & 0 & 1 & 1 & 0 & 0 & 0 & 0 & 0 & 0 & 0 \\
\hline C. carpio & 1 & 1 & 1 & 1 & 1 & 1 & 1 & 1 & 1 & 1 & 1 & 1 & 1 & 1 & 1 & 1 & 1 & 1 & 1 & 1 & 1 & 1 \\
\hline Ch.p.polylepis & $\mathrm{O}$ & 1 & 1 & 1 & 1 & 1 & 1 & 1 & 1 & 1 & 1 & 0 & 0 & 0 & 0 & 0 & 0 & 0 & 0 & 0 & $\mathrm{O}$ & 0 \\
\hline Ch.p. willkommi & 0 & 0 & 0 & 0 & 0 & 0 & 0 & 0 & 0 & 0 & 0 & 1 & 1 & 1 & 1 & 1 & 1 & 0 & 0 & 0 & 0 & 0 \\
\hline Ch.t.toxosostma & 1 & 0 & 0 & 0 & 0 & 0 & 0 & 0 & 0 & 0 & 0 & 0 & 0 & 0 & 0 & 0 & 0 & 0 & 0 & 0 & 1 & 0 \\
\hline Ch.t. arrigonis & 0 & 0 & 0 & 0 & 0 & 0 & 0 & 0 & 0 & 0 & 0 & 0 & 0 & 0 & 0 & 0 & 0 & 1 & 1 & 0 & 0 & 0 \\
\hline G. gobio & 1 & 1 & 1 & 1 & 1 & 1 & 1 & 1 & 1 & 1 & 1 & 1 & 1 & 1 & 1 & 0 & 1 & 1 & 1 & 1 & 1 & 0 \\
\hline I. palaciosi & 0 & 0 & 0 & 0 & 0 & 0 & 0 & 0 & 0 & $\mathrm{O}$ & 0 & 0 & 0 & 0 & 1 & 0 & 0 & 0 & 0 & 0 & 0 & 0 \\
\hline L. carolitertis & 0 & 1 & 1 & 1 & 1 & 1 & 1 & 0 & 0 & 0 & 0 & 0 & 0 & 0 & 0 & 0 & 0 & 0 & 0 & 0 & 0 & 0 \\
\hline L. cephalus & 0 & 0 & 0 & 0 & 0 & 0 & 0 & 0 & 0 & 0 & 0 & 0 & 0 & 0 & 0 & 0 & 0 & 0 & 0 & 0 & 1 & 1 \\
\hline L. pyrenaicus & 0 & 0 & 0 & 0 & 0 & 0 & 0 & 1 & 1 & 1 & 1 & 1 & 1 & 1 & 1 & 1 & 1 & 1 & 1 & 1 & 0 & 0 \\
\hline P.phoxinus & 1 & 0 & 0 & 0 & 0 & 0 & 1 & 0 & 0 & 0 & 0 & 0 & 0 & 0 & 0 & 0 & 0 & 0 & 0 & 0 & 1 & 1 \\
\hline R. alburnoides & 0 & 0 & 0 & 0 & 0 & 0 & 1 & 1 & 1 & 1 & 1 & 1 & 1 & 1 & 1 & 1 & 0 & 0 & 0 & 0 & 0 & 0 \\
\hline R. a. arcasii & 1 & 0 & 0 & 0 & 0 & 0 & 1 & 1 & 0 & 1 & 1 & 0 & 0 & 1 & 0 & 0 & 0 & 1 & 0 & 1 & 0 & 0 \\
\hline \multicolumn{23}{|l|}{ R. a. macrolepi- } \\
\hline dotus & 0 & 0 & 0 & 0 & 0 & 0 & 1 & 1 & 1 & 1 & 0 & 0 & 0 & 0 & 0 & 0 & 0 & 0 & 0 & 0 & 0 & 0 \\
\hline R. lemmingii & 0 & 0 & 0 & 0 & 0 & 0 & 1 & 1 & 1 & 1 & 1 & 1 & 1 & 1 & 1 & 0 & 0 & 0 & 0 & 0 & 0 & 0 \\
\hline R. rutilus & 0 & 0 & 0 & 0 & 0 & 0 & 0 & 0 & 0 & 0 & 0 & 0 & 0 & 0 & 0 & 0 & 0 & 0 & 0 & 0 & 0 & 1 \\
\hline \multicolumn{23}{|l|}{ S. erythrophthal- } \\
\hline mus & 0 & 0 & 0 & 0 & 0 & 0 & 0 & 0 & 0 & 0 & 0 & 0 & 0 & 0 & 0 & 0 & 0 & 0 & 0 & 0 & 0 & 1 \\
\hline T. tinca & 0 & 0 & 0 & 0 & 0 & 0 & 1 & 0 & 0 & 1 & 0 & 0 & 0 & 1 & 1 & 0 & 0 & 0 & 0 & 0 & 0 & 0 \\
\hline
\end{tabular}


Table 3. Distribution of the species in the different river basins. The codes used are those of Table 4 and figure 1.

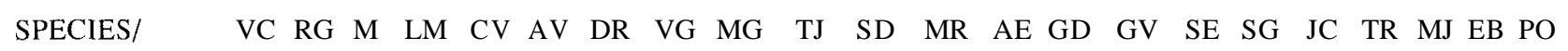
BASINS

\begin{tabular}{|c|c|c|c|c|c|c|c|c|c|c|c|c|c|c|c|c|c|c|c|c|c|c|}
\hline C. calderoni & 0 & 0 & 0 & 0 & 0 & 0 & 1 & 1 & 1 & 1 & 0 & 0 & 0 & 0 & 0 & 0 & 0 & 0 & 0 & 0 & 0 & 0 \\
\hline C. maroccana & 0 & 0 & 0 & 0 & 0 & 0 & 0 & 0 & 0 & 1 & 1 & 1 & 1 & 1 & 1 & 1 & 1 & 1 & 1 & 1 & 1 & 0 \\
\hline N. barbatulus & 1 & 0 & 0 & 0 & 0 & 0 & 0 & 0 & 0 & 0 & 0 & 0 & 0 & 0 & 0 & 0 & 0 & 0 & 0 & 0 & 1 & 0 \\
\hline S. glanis & 0 & 0 & 0 & 0 & 0 & 0 & 0 & 0 & 0 & 0 & 0 & 0 & 0 & 0 & 0 & 0 & 0 & 0 & 0 & 0 & 0 & 1 \\
\hline 1. melas & 0 & 0 & 0 & 0 & 0 & 0 & 0 & 0 & 0 & 0 & 0 & 0 & 0 & 0 & 0 & 0 & 0 & 0 & 0 & 0 & 1 & 1 \\
\hline A. iberus & 0 & 0 & 0 & 0 & 0 & 0 & 0 & 0 & 0 & 0 & 0 & 0 & 0 & 0 & 1 & 1 & 1 & 1 & 1 & 1 & 1 & 1 \\
\hline$F$. heteroclitus & 0 & 0 & 0 & 0 & 0 & 0 & 0 & 0 & 0 & 0 & 0 & 1 & 1 & 1 & 1 & 0 & 0 & 0 & 0 & 0 & 0 & 0 \\
\hline$V$. hispanica & 0 & 0 & 0 & 0 & 0 & 0 & 0 & 0 & 0 & 0 & 0 & 0 & 0 & 0 & 0 & 0 & 0 & 0 & 1 & 1 & 1 & 1 \\
\hline G. affinis & 1 & 1 & 1 & 1 & 1 & 1 & 1 & 1 & 1 & 1 & 1 & 1 & 1 & 1 & 1 & 1 & 1 & 1 & 1 & 1 & 1 & 1 \\
\hline A. boyeri & 1 & 1 & 1 & 0 & 0 & 0 & 0 & 0 & 0 & 1 & 1 & 1 & 1 & 1 & 1 & 1 & 1 & 1 & 1 & 1 & 1 & 1 \\
\hline G. aculeatus & 1 & 1 & 1 & 1 & 0 & 1 & 1 & 1 & 1 & 1 & 1 & 0 & 0 & 1 & 1 & 1 & 0 & 1 & 0 & 0 & 1 & 1 \\
\hline S. abaster & 0 & 0 & 0 & 0 & 0 & 0 & 0 & 0 & 0 & 0 & 0 & 0 & 0 & 1 & 1 & 1 & 1 & 1 & 1 & 1 & 1 & 1 \\
\hline C. gobio & 1 & 0 & 0 & 0 & 0 & 0 & 0 & 0 & 0 & 0 & 0 & 0 & 0 & 0 & 0 & 0 & 0 & 0 & 0 & 0 & 1 & 0 \\
\hline$P$. fluviatilis & 0 & 0 & 0 & 0 & 0 & 0 & 0 & 0 & 0 & 0 & 0 & 0 & 0 & 0 & 0 & 0 & 0 & 0 & 0 & 0 & 1 & 1 \\
\hline S. lucioperca & 0 & 0 & 0 & 0 & 0 & 0 & 0 & 0 & 0 & 0 & 0 & 0 & 0 & 0 & 0 & 0 & 0 & 0 & 0 & 0 & 0 & 1 \\
\hline D. labrax & 1 & 1 & 1 & 0 & 0 & 0 & 0 & 0 & 0 & 0 & 1 & 1 & 1 & 1 & 1 & 1 & 1 & 1 & 1 & 1 & 1 & 1 \\
\hline D. punctata & 1 & l & 1 & 0 & 0 & 0 & 0 & 0 & 0 & 0 & 1 & 1 & 1 & 1 & 1 & 1 & 1 & 1 & 1 & 1 & 1 & 1 \\
\hline L. gibbosus & 0 & 0 & 0 & 0 & 0 & 0 & 0 & 0 & 0 & 1 & 1 & 1 & 1 & 1 & 1 & 0 & 0 & 0 & 0 & 0 & 0 & 1 \\
\hline M. salmoides & 1 & 1 & 1 & 1 & 1 & 1 & 1 & 1 & 1 & 1 & 1 & 1 & 1 & 1 & 1 & 1 & 1 & 1 & 1 & 1 & 1 & 1 \\
\hline Ch. labrosus & 1 & 1 & 1 & 0 & 0 & 0 & 0 & 0 & 0 & 0 & 1 & 1 & 1 & 1 & 1 & 1 & 1 & 1 & 1 & 1 & 1 & 1 \\
\hline L. aurata & 1 & 1 & 1 & 0 & 0 & 0 & 0 & 0 & 0 & 0 & 1 & 1 & 1 & 1 & 1 & 1 & 1 & 1 & 1 & 1 & 1 & 1 \\
\hline L. ramada & 1 & 1 & 1 & 0 & 0 & 0 & 0 & 0 & 0 & 0 & 1 & 1 & 1 & 1 & 1 & 1 & 1 & 1 & 1 & 1 & 1 & 1 \\
\hline L. saliens & 1 & 1 & 1 & 0 & 0 & 0 & 0 & 0 & 0 & 0 & 1 & 1 & 1 & 1 & 1 & 1 & 1 & 1 & 1 & 1 & 1 & 1 \\
\hline M. cephalus & 1 & 1 & 1 & 0 & 0 & 0 & 0 & 0 & 0 & 0 & 1 & 1 & 1 & 1 & 1 & 1 & 1 & 1 & 1 & 1 & 1 & 1 \\
\hline$P$. fluviatilis & 0 & 0 & 0 & 0 & 0 & 0 & 0 & 0 & 0 & 0 & 0 & 0 & 1 & 1 & 0 & 0 & 0 & 1 & 0 & 0 & 1 & 1 \\
\hline P. microps & 1 & 1 & 1 & 0 & 0 & 0 & 0 & 0 & 0 & 0 & 1 & 1 & 1 & 1 & 1 & 1 & 1 & 1 & 1 & 1 & 1 & 1 \\
\hline P. minutus & 1 & 1 & 1 & 0 & 0 & 0 & 0 & 0 & 0 & 0 & 1 & 1 & 1 & 1 & 1 & 1 & 1 & 1 & 1 & 1 & 1 & 1 \\
\hline P. flexus & 1 & 1 & 1 & 0 & 0 & 0 & 0 & 0 & 0 & 0 & 1 & I & 1 & 1 & 1 & 1 & 1 & 1 & 1 & 1 & 1 & 1 \\
\hline C. facetum & 0 & 0 & 0 & 0 & 0 & 0 & 0 & 0 & 0 & 0 & 1 & 1 & 1 & 1 & 0 & 0 & 0 & 0 & 0 & 0 & 0 & 0 \\
\hline
\end{tabular}

more of are introduction, as it has been found in the fossil layer of the early Pleistocene in Arganda, Madrid (MORALES, 1980). When more data is available, it may well be considered a native species of the Iberian Peninsula.

At present many changes are occurring, as species are being moved between different river basins. Live bait has been used to catch predator species, which are then released in other river basins, as has been the case with Lepomis gibbosus, introduced into the Guadalquivir in the province of Cordoba from the Guadiana. Indiscriminate release by aquarium owners is another cause, and may explain the presence of Fundulus heteroclitus, Cichlasoma facetum. Carassius auratus and Carassius carassius.
The Government, to satisfy ever increasing demand from anglers, has made massive introductions of fish from Germany, Italy. France and the USA. The fish involved are brown trout, rainbow trout, pike, largemouth bass and pumkinseed sunfish.

Some species such as Hucho hucho, Salvelinus fontinalis. Ictalurus melas and Silurus glanis show a limited distribution despite having been introduced in several areas. On the other hand, species such as Esox lucius, Micropterus salmoides, Lepomis gibbosus and Gambusia affinis are very widely distributed. Fundulus heteroclitus and Cichlasoma facetum have been found in the river basins of the South of Portugal, the Guadiana and the Guadalquivir, but their 


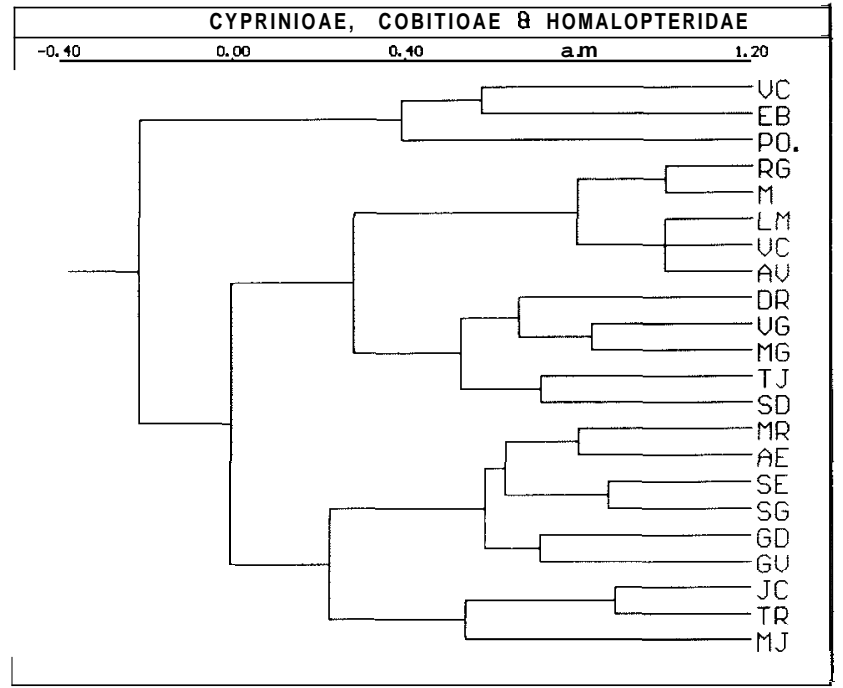

Figure ', Sectorization of the Iberian Peninsula. The initials of the river basins are those of Table 4. distribution area is spreading. As for Cichlasoma facetum, the first known samples are from the River Mira (HELLING, 1943). spreading later towards the South of Portugal (ALMAÇA, 1964; COLLARES-PEREIRA, 1985), and subsequently to the Guadiana basin (PEIRO, 1987).

\section{SECTORISATION OF THE IBERIAN PENINSULA}

There have been several attempts to divide the Iberian Peninsula into sectors of freshwater fauna. AREVALO (1929) proposed a model based on the presence or absence of salmon and ciprinodontiforms, with three "provinces": Cantabria, the Atlantic and the Betico-Mediterranean. LOZANO (1952), based his model on the presence or absence of Cyprinidae, Cobitidae and Cyprinodontidae, and reduced the number of "regions" to two: Northern and Southern. ALMAÇA (1978) and HERNANDO et al., (1982)

Table 4. Number of species catalogued in the Iberian Peninsula river basins, using those whose surface is equal to or greater than 990 square kilometres. (NAT: native; END: endemic: INT: introduced).

\begin{tabular}{|c|c|c|c|c|c|c|}
\hline \multirow[t]{2}{*}{ RIVER BASINS } & \multicolumn{2}{|c|}{ SURFACE AREA $\left(\mathrm{Km}^{2}\right)$} & \multicolumn{4}{|c|}{ SPECIES } \\
\hline & & & NAT & END & INT & TOTAL \\
\hline CANTABRIAN BASINS & $\mathrm{VC}$ & 24382 & 23 & 3 & 6 & 32 \\
\hline RIVERS OF GALICIA & RG & 11225 & 19 & 2 & 7 & 28 \\
\hline MIÑO & M & 16800 & 19 & 2 & 7 & 28 \\
\hline LIMIA & LM & 2515 & 6 & 3 & 7 & 16 \\
\hline CAVADO & $\mathrm{CV}$ & 1680 & 5 & 3 & 7 & 15 \\
\hline AVE & $\mathrm{AV}$ & 1520 & 6 & 3 & 7 & 16 \\
\hline DUERO & DR & 97710 & 9 & 7 & 8 & 24 \\
\hline VOUGA & $V G$ & 3150 & 6 & 9 & 6 & 21 \\
\hline MONDIGO & MG & 6350 & 5 & 7 & 6 & 18 \\
\hline TAJO & $\mathrm{TJ}$ & 80400 & 8 & 10 & 10 & 28 \\
\hline SADO & SD & 6500 & 15 & 8 & 7 & 30 \\
\hline MIRA & MR & 1530 & 12 & 8 & 8 & 28 \\
\hline ALGARVE & $\mathrm{AE}$ & 990 & 12 & 7 & 8 & 27 \\
\hline GUADIANA & GD & 72337 & 20 & 11 & 10 & 40 \\
\hline GUADALQUIVIR & GV & 56528 & 20 & 8 & 11 & 39 \\
\hline BASINS OF SOUTHERN SPAIN & $\mathrm{SE}$ & 23121 & 15 & 6 & 4 & 25 \\
\hline SEGURA & SG & 15803 & 15 & 5 & 6 & 26 \\
\hline JUCAR & $\mathrm{JC}$ & 22651 & 17 & 7 & 7 & 31 \\
\hline TURIA & $\mathrm{TR}$ & 6808 & 14 & 8 & 7 & 29 \\
\hline MIJARES & MJ & 7966 & 14 & 5 & 7 & 26 \\
\hline EBRO & EB & 83000 & 24 & 7 & 10 & 41 \\
\hline WESTERN PYRENEES & PO & 16826 & 20 & 4 & 12 & 36 \\
\hline
\end{tabular}


propose two different models, both based on the distribution of Cyprinidae and Cobitidae. In the first, there are three "subdistricts" or "subsectors": Ebro-Cantabria, Central and Southern, and in the second there are two subregions: the North Atlantic and the Betico-Meditteranean.

Although HERNANDO (1990) considers this latter subregionalization to be valid, we believe that the new data on Cyprinidae, Cobitidae and Homalopteridae (strictly freshwater species), the description of a new species of the Leusicus genus, the variation in the distribution of Anaecypris hispanica, etc., justify a new attempt to clarify the sectorisation or subregionalisation of the Iberian Peninsula.

This will be based on the distribution matrix (presenceabsence) of the species and subspecies of these families in the 22 river basins with a surface area of more than $990 \mathrm{~km}^{2}$ (table 2). The river basins are grouped using the PHI similarity index (ROHLF, 1988) and then a UPGM-type cluster analysis (ROHLF, op. ct.), considering species and subspecies as identical.

Three different models were made to determine which most closely represents the distribution of species in river basins. The first includes species and subspecies of Cyprinidae, Cobitidae and Homalopteridae (fig. 1). The second adds Blennius fluviatilis, Cottus gobio and Lampetra planeri to these families, and the third includes all 35 species and subspecies under consideration (table 3 ).

The results show three groups of river basins (fig 1). The first group includes the Ebro, Cantabria and the eastern Pyrenees. The second has two subgroups: the Gallegos, Miño, Limia, Cavado and Ave, and the Duero, Vouga, Mondego, Tajo and Sado. The third group includes the South of Spain and the Segura, and the Jucar, Turia and Mijares on the Mediterranean.

This pattern is repeated for the other models, and demonstrates the strong influence of the Cyprinidae, Cobitidae and Homalopteridae families with respect to the other species. It is thus proposed to consider the Iberian Peninsula as being divided into three subregions or subsectors: the Ebro-Cantabrian, the Atlantic and the Betico-Mediterranean.

\section{REFERENCES}

ALMAÇA, C., 1964. Contribuçao para o conhecimiento da fauna ictiologica das aguas interiores portuguesas. Bol.

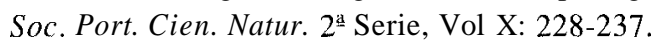

ALMAÇA, C., 1967. Estudo das populaçoes portuguesas do Gén. Barbus Cuvier, 1817 (Pisces: Cyprinidae). Rev. Fac. Cien. Lisboa, 14 (2):151-400.

ALMAÇA, C., 1972. Sur la systématique des Barbeaux (genre et sousgenre Barbus) de la Péninsule Iberique et de l'Afrique du Nord. Arq. Mus. Boc. 3, ñ 10: 319-346.

ALMAÇA, C., 1976. La speciation chez les cyprinidae de la Peninsule Iberique. Rev. Trav. Inst. Peches Mart. 40 (3-4): 399-411.

ALMAÇA, C., 1978. Repartition geographique des Cyprinidaes iberiques et secteurs ichthyogeographiques de la Péninsule Iberique. Ves. Cesk. Spole Zool. XLII 4: 241248.

ALMAÇA, C., 1984. Form relationships among western paleartic species of Barbus (Cyprinidae, Pisces). Arq. Mus. Boc. Serie A, Vol II, 12: 207-248.

AREVALO, C., 1929. La vida en las aguas dulces. Ed. Labor. Barcelona. 198 pp.

BANARESCU, P., 1972. The zoogeographical position of the East Asian fresh-water fish fauna. Rev. Roum. Biol. Zool. 17 (5): 315-323.

BANARESCU, P., 1973 a. Origin and affinities of the freshwater fish fauna of Europe. Ichthyologia. 5: 1-8.

BANARESCU, P., 1973 b. Some reconsiderations on the zoogeography of the euro-mediterranean fresh-water fish fauna. Rev. Roum. Biol. Zool. 18 (4): 257-264.

BUEN, F. DE ., 1935. Fauna ictiológica. Catálogo de los peces ibéricos de la planicie continental, aguas dulces, pelágicos y de los abismos próximos. Inst. Esp. Ocean. Nat. y Res. Sr. II 88.

COLLARES-PEREIRA, M. J., 1983. Estudio sitematico e citogenetico dos pequenos cyprinideos ibericos pertenecientes aos generos Chondrostoma Agassiz, 1835, Rutilus Rafinesque, 1820 e Anaecypris. Ph. D. Thesis Mus. Boc., University of Lisboa, $511 \mathrm{pp}$.

COLLARES-PEREIRA, M. J., 1984. The "Rutilus alburnoides (Steindachner, 1866) complex" (Pisces: Cyprinidae). I.- Biometrical analisys of zone portuguese populations. Arq. Mus. Boc. II (8) 2: 11-143.

COLLARES-PEREIRA, M. J., 1985 a. The "Rutilus alburnoides (Steindachner, 1866) complex" (Pisces: Cyprinidae). II.- First data on the caryology of a well established diploid-triploid group. Arq. Mus. Boc. III (S): 69-90.

COLLARES-PEREIRA, M. J., 1985 b. Ciprinideos do Alentejo. De (FROM) Congresso sohre o Alentejo, Evora. Vol II: 537-545.

DEMESTRE, M., A. ROIG, A. DE SOSTOA \& F. M. DE SOSTOA., 1977. Contriboció a l'estudi de la ictiofauna 
continental del delta de l'Ebre. Trab. Inst. Cat. Hist. Nat. 8: 145- 226.

DOADRIO, I., 1984. Relaciones filogenéticas y biogeográficas de los barbos (Barbus, Cyprinidae) de la Península Ibérica y aportes corológicos y biogeográficos a su ictiofauna continental. Ph. D. Thesis. Complutense University of Madrid. $1119 \mathrm{pp}$.

DOADRIO, I., 1986. Ictiofauna de la Comunidad Autónoma de Extremadura. Informe preliminar. Dirección General de Medio Ambiente. Junta de Extremadura.

DOADRIO, I., 1987. Leuciscus carolitertis n. sp. from the Iberian Peninsula (Pisces: Cyprinidae). Senken. Biol., 68: 4-6.

ELVIRA, B., 1986. Revisión taxonómica y distribución geográfica del género Chondrostoma Agassiz, 1835 (Pisces: Cyprinidae). Ph. D. Thesis. INIA. Ministry of Agricultura. Madrid. 62: 1- 530.

ELVIRA, B., 1987. Taxonomic revisión of the genus Chondrostoma Agassiz, 1835 (Pisces: Cyprinidae). Cyhium 11 (2): 11-140.

FERNANDEZ-DELGADO, C., J. A. HERNANDO, M. HERRERA \& M. BELLIDO, 1986. Sobre el status taxonómico del género Vulencia (Myers, 1928) en el suroeste de Iberia. Doñana Acta Vertebrata 13: 161-163.

GARCIA DE JALON, D \& M. GONZALEZ DEL TANAGO, 1983. Estudio biotopológico de las comunidades piscícolas de de la cuenca del Duero. Bol. Est. Cent. Ecol. 12: 57-66.

GARCIA DE JALON, D \& J. V. LOPEZ ALVAREZ, 1983. Distribución geográfica y mesológica de las especies piscícolas de la cuenca del Duero en el verano de 1981. Actas $1^{\circ}$ Congr. Esp. Limnol. 227-235.

HELLING, $H ., 1943$. Novo catálogo dos peixes de Portugal em colecçao no Museu de Zoologia de Universidade de Coimbra. Men. Est. Mus. Zool. Univ. Coimbra, 149. 110 pp.

HERNANDO, J. A., 1975 a. Notas sobre la distribución de los peces fluviales en el suroeste de España. Doñana Acta Vertehrata 2 (2): 263-264.

HERNANDO, J. A., 1975 b. Nuevas localidades de Valencia hispanica (Pisces: Cyprinodontidae) en el suroeste de España. Doñana Acta Vertehrata. 13: 265267.

HERNANDO, J. A., 1990. Ictiofauna del río Guadalquivir: Características y perspectivas. In: Avances en el cono- cimiento y gestion del medio ambiente de Córdoba. A. López \& J. M. Recio (Eds) . 35-62.

HERNANDO, J. A. I. DOADRIO \& C. FERNANDEZDELGADO, 1982. Distribución geográfica y diversidad de la ictiofauna continental ibérica. Modelo inicial. Res. IIJor. Ictiol. Iherica. Barcelona. Mayo 1983.

ICONA, 1986. Lista roja de los Vertehrados de España. Publ. Minist. Agric., Pesca y Aliment. Madrid. 400 pp.

LOBON- CERVIA, J., B. ELVIRA \& P. RINCON, 1989. Historical changes in the fish fauna of the river Duero basin. In Historical change of large alluvial rivers: Western Europe. (G.E. Pett, H. Moller \& A. L. Roux, eds.): 221 232. John Wiley \& Sons. Chichester. 355 pp.

LOBON-CERVIA, J \& B. ELVIRA, 1989. Estado de conservación de los peces fluviales ibéricos. Quercus 44: 24-27.

LOZANO REY, L., 1935. Los peces fluviales de España. Mem. Real Acad. Cien. Ex. Fis. Nat. Tomo V. Madrid.

LOZANO REY, L., 1952. Los peces fluviales de España. Min. Agricultura. Madrid.

MORALES, A., 1980. Los peces fósiles del yacimiento Achelense de Aridos- 1 (Arganda, Madrid). Ocupaciones Achelenses en el valle del Jarama. Publ. Exma. Diputación Prov. Madrid. 93-104.

MYERS, G. S., 1960. The endemic fish fauna of the lake Lanao, and the evolution of higher taxonomic categories. Evolution, 14 (3): 323-333.

PEIRO, S., 1987. Una excursión por la cuenca del Guadiana. Aquamar, 25: 32-33.

ROHLF, F. J., 1988. NTSYS-pc: Numerical tasonomic and Multivariante Analysis System. Exeter Publishing Ltd. New York. 129 pp.

SOSTOA, A., F. J. SOSTOA, J. LOBON- CERVIA, B. ELVIRA, J. A. HERNANDO \& M. AVILA., 1984. Atlas y distribución de los peces de agua dulce de España: el proyecto, métodos y resultados preliminares. Bol. Est. Cent. Ecol. 13 (25): 75-81.

SOSTOA, A. \& J. LOBON-CERVIA., 1989. Fish and fisheries of the river Ebro: actual state and recent history. In: Historical change of large alluvial rivers: Western Europe. (G.E. Pett, H. Moller \& A. L. Roux, eds.): 233 247. John Wiley \& Sons. Chichester. 355 pp.

TERMIER, H. et G.. 1960. Atlas de Paléogéogruphie. Masson. Paris. 